University of Rhode Island

DigitalCommons@URI

The Rhode Island Current Conditions Index

Economics

2-2005

\title{
Rhode Island Current Conditions Index - February 2005
}

Leonard Lardaro

University of Rhode Island, lardaro@uri.edu

Follow this and additional works at: https://digitalcommons.uri.edu/ricci

Part of the Econometrics Commons

Terms of Use

All rights reserved under copyright.

\section{Recommended Citation}

Lardaro, Leonard, "Rhode Island Current Conditions Index -- February 2005" (2005). The Rhode Island Current Conditions Index. Paper 105.

https://digitalcommons.uri.edu/ricci/105

This Article is brought to you for free and open access by the Economics at DigitalCommons@URI. It has been accepted for inclusion in The Rhode Island Current Conditions Index by an authorized administrator of DigitalCommons@URI.For more information, please contact digitalcommons-group@uri.edu. 


\section{Current Conditions I ndex \\ LEONARD LARDARO URI}

Also available online: http:/ / members.cox.net/ lardaro/ current.htm

Volume XI, Number 5

February 2005

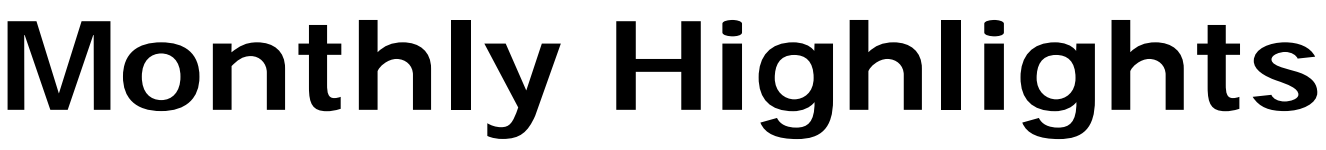

February saw a continuation of Rhode Island's slow but sustainable pace of economic activity. The Current Conditions Index rose from 50 in January to 58 in February, as seven indicators improved. Like January, there were several strong indicator performances. Unlike last month, weather-induced distortions of economic indicators were largely absent.

Government Employment rose for only the third time in the past thirteen months. So far, a short-lived uptrend in this indictor appears to be forming, in spite of budget tightening at all levels of government. Labor demand, in terms of adjusted Help Wanted Advertising, weakened a bit in February, rising by only 3.3 percent, about half its growth rate over the past two months. Job prospects also improved at a slower rate in February, as Private Service-Producing Employment

\begin{tabular}{lr}
\multicolumn{2}{c}{ CCI I ndicators - \% Change } \\
Government Employment & 0.2 Y \\
US Consumer Sentiment & -0.3 \\
Single-Unit Permits & -3.0 \\
Retail Sales & $6.1 \mathrm{Y}$ \\
Help Wanted Advertising & $3.3 \mathrm{Y}$ \\
Priv. Serv-Prod Employment & $2.2 \mathrm{Y}$ \\
Man-Hours Manufacturing & -4.6 \\
Manufacturing Wage & $0.5 \mathrm{Y}$ \\
Labor Force & -0.0 \\
Benefit Exhaustions & $-12.5 \mathbf{Y}$ \\
New Claims & 0.1 \\
Unemployment Rate & $-18.5 \mathrm{Y}$ \\
\multicolumn{1}{|c}{$\mathbf{Y}=$ I mproved Value }
\end{tabular}

increased by 2.2 percent. In spite of both improvements, layoffs still rose slightly, as New Claims increased by 0.1 percent. By way of contrast, Benefit Exhaustions, which reflects long-term unemployment, fell sharply in February, by 12.5 percent, offering hope that its medium-term downtrend is still in tact.

Two of the stronger indicators of late, Retail Sales and US Consumer Sentiment, diverged in February. Retail Sales rose by a very healthy 6.1 percent compared to last February, as both weather problems and heavy post-holiday discounting ended. US Consumer Sentiment fell slightly, by 0.3 percent compared with last February. But this is not really that negative a performance, as the annual growth rate in this indicator last February was 18.4 percent. So, the performances of both Retail Sales and US Consumer Sentiment are reflective of underlying strength and continued momentum.
Rhode Island's manufacturing sector turned in another mixed performance in February, as Manufacturing Man-hours fell by 4.6 percent compared to last February. While this was an improvement over the past two months, it was the third largest decline in over a year. Manufacturing Wage growth slowed again, from 0.8 percent in January to only 0.5 percent in February. This has kept Rhode Island's average hourly Manufacturing Wage barely above the $\$ 13$ mark on a seasonally adjusted basis. New home construction fell less sharply in February than it had in January, as Single-Unit Permits declined by 3 percent compared to last February. Part of the improvement was the result of improved weather effects versus one year ago.

On a year-over-year basis, Rhode Island's Labor Force was unchanged, a distinct improvement over what we have witnessed over the past several months. Better yet, compared to last month, our Labor Force grew by 3,200, which translated into a rise of 3,000 in resident employment and only 200 more unemployed. So, ironically, while February's Unemployment Rate was unchanged from J anuary, our labor market displayed a great deal more strength, which makes the large yearly decline (from $5.4 \%$ to $4.4 \%$ ) more meaningful.

Looking at that 2005 thus far, Rhode Island's economy continues to move forward, albeit at rates that remain somewhat disappointing. It is important for us to keep in mind that we are not witnessing across-the-board weakness. Instead, much of our strength continues to be offset by weaknesses in other sectors. Hopefully this highly frustrating situation will improve in the next few months.

\section{Current Conditions I ndex}

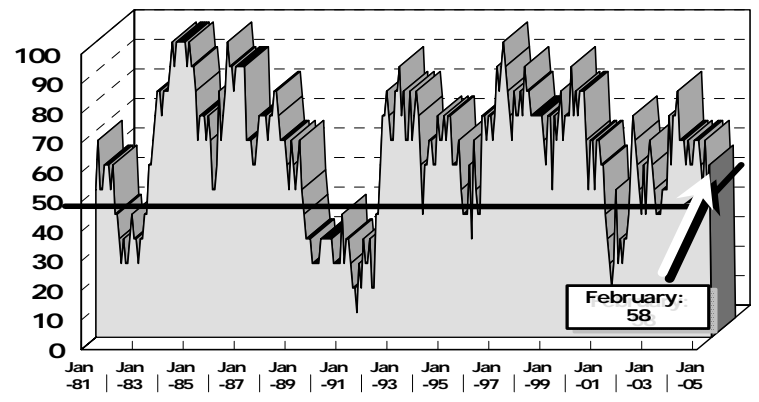

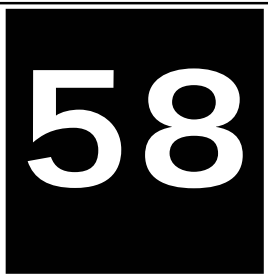

\begin{tabular}{|c|c|c|c|c|c|c|c|c|c|c|c|c|}
\hline & Jan & Feb & Mar & Apr & May & J un & J ul & Aug & Sep & Oct & Nov & Dec \\
\hline 2004 & 67 & 67 & 58 & 67 & 58 & 58 & 67 & 67 & 67 & 58 & 50 & 67 \\
\hline 2005 & 50 & 58 & & & & & & & & & & \\
\hline
\end{tabular}

Copyright @ 2004, 2005 Leonard Lardaro, Ph.D. All rights reserved. 